\title{
Article
}

\section{Developing the mindful nurse practitioner}

Baverstock, Simon and Hulatt, Ian

Available at http://clok.uclan.ac.uk/33607/

Baverstock, Simon ORCID: 0000-0003-3335-8108 and Hulatt, Ian (2020)

Developing the mindful nurse practitioner. Mental Health Practice . ISSN 14658720

It is advisable to refer to the publisher's version if you intend to cite from the work. http://dx.doi.org/10.7748/mhp.2020.e1406

For more information about UCLan's research in this area go to

http://www.uclan.ac.uk/researchgroups/ and search for < name of research Group>.

For information about Research generally at UCLan please go to http://www.uclan.ac.uk/research/

All outputs in CLoK are protected by Intellectual Property Rights law, including Copyright law. Copyright, IPR and Moral Rights for the works on this site are retained by the individual authors and/or other copyright owners. Terms and conditions for use of this material are defined in the policies page.

\section{CLoK}

Central Lancashire online Knowledge www.clok.uclan.ac.uk

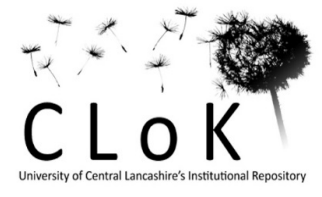




\section{'The Mindful Nurse Practitioner: A Discussion Paper'}

\section{Introduction:}

The reflective practitioner (Schon, 1983) continues to hold relevance in nurse education and clinical practice (Oates, 2017). The concept of reflection continues to be considered extremely relevant to experiential learning and professional development (Moon, 1999; 2004). Furthermore, to continuously self-reflect and carefully consider actions is a proficiency of the future accountable nurse (NMC, 2018). Although the ability to reflect upon one's own actions in retrospect is likely to influence future practice, could developing an increased capacity to being more fully aware of the present moment reduce the need for retrospective reflection? By offering courses in mindfulness, we could possibly develop nurse education to build on the idea of the reflective practitioner, towards a 'mindful nurse practitioner', one that has greater capacity for present moment awareness, presence, compassion and self-care that positively benefits client care. The intention of this discussion paper is not to dismiss or argue against the value that reflection has in both nurse education and in practice, but to keep up the momentum of raising awareness of the growing evidence base of mindfulness, which we argue is essential in developing nurses of the future through mindfulness practice. Following a brief introduction to mindfulness, consideration will be given to the growing evidence of mindfulness in nursing and nurse education including the benefits it offers the profession.

\section{What is mindfulness?}

For over two and a half thousand years, mindfulness has been a central discipline in all systems of Buddhist meditation (Bodhi, 2011; Kabat-Zinn, 1990; Thera, 1962). Jon Kabat Zinn first introduced mindfulness in Western medicine in the late 1970's (Kabat-Zinn, 1990) in the form of an eight-week course that developed the title Mindfulness-Based Stress Reduction (MBSR), which was essentially an introduction to mindfulness meditation and yoga. Following initial screening and either an interview or group orientation, a typical eight week course follows a specific and well developed curriculum (Santorelli, Meleo-Meyer \& Koerbel, 2017), which involves attending weekly two to three hour group sessions and a full day retreat between session six and seven. There is an expectation to practice the meditations and skills learnt within each session daily over the week before the following session. 
Participants attend with various physical and mental conditions. Following completion of courses participant report a greater relief from their suffering than previous medical treatments and procedures they have engaged with (Kabat-Zinn, 1990). On a basic but profound level mindfulness is paying attention to the present moment that includes awareness of all sensory experience, the mind, other people and the environment. One popular definition of mindfulness is "Paying attention in a particular way: on purpose, in the present moment, and non-judgementally" (Kabat-Zinn, 1994, p.4). In addition, the practice of mindfulness fosters the cultivation of many attitudes that include curiosity, acceptance, kindness and compassion. The value of these skills can result in various benefits to those who commit to this type of training and ongoing practice.

The science of meditation has a growing field of research (Goleman \& Davidson, 2017). Although, there are many methodological issues with much of the available research, along with a lack of consistency to define mindfulness and meditation (van Dam et al, 2017), the pioneers and researchers in this field are extremely transparent about these flaws with the intention to develop the strength of future research (Goleman \& Davidson, 2017; van Dam et al, 2017). Yet, the current body of evidence demonstrates how mindfulness meditation skills can develop improved executive functioning, attention regulation, sensory processing, memory and the regulation of the stress response (Brtton, 2016). Meditation practice essentially develops a greater sense of self-awareness paramount to emotional intelligence (Goleman, 1995).

The cultivation of mindfulness is described as 'a way of being' (Kabat-Zinn, 1994) as it can awaken a new perspective of life as if seeing the world through a new lens. The interest in mindfulness meditation in Western society has become extremely popular within the field of medicine and psychology for its use with patients who experience physical and mental suffering. Adapted MBSR programmes for specific vulnerabilities have been developed in recent decades such as the third wave Cognitive Behaviour Therapy Mindfulness-Based Cognitive Therapy (MBCT) (Segal, Williams \& Teasdale, 2013) that is a recommended psychological interventions for relapse prevention in depression (National Institute for Health and Care Excellence, 2009). Although MBCT is only one of the many mindfulness-based interventions that is available in health care, various other fields have developed mindfulness- 
based programmes, for example in education, the workplace and the criminal justice system gaining support from parliament (The Mindfulness All-Party Parliamentary Group, 2015).

Although the research evidence currently is far more robust in health care than it is in other fields, it is wise and ethical to exercise restraint before delivering training in mindfulness everywhere. A common recommendation is that when offering mindfulness in any field, a competent mindfulness practitioner delivers these courses (Crane, Kuyken, Williams, Hastings, Cooper \& Fennell, 2012; UK Network for Mindfulness-Based Teachers, 2011).

\section{The Mindful Nurse Practitioner}

The mindful nurse practitioner is not an original concept, but has been discussed in previous publications highlighting the value that mindfulness practice offers the nursing profession, both in clinical and leadership roles (Howland \& Bauer-Wu, 2015; Pipe, FitzPatrick, Doucette, Cotton \& Arnow, 2016; Sheridan, 2016). The nursing profession involves greater pressure than ever before. It is the growing evidence base of developing mindfulness skills/practice in higher education and nurse education which is becoming increasingly compelling. It is argued that these skills need to be readily available in the education of future nurses, that could help foster greater present moment awareness and build on the skill of reflective practice towards becoming a more mindful nurse practitioner.

\section{Mindfulness in higher education}

In higher education more and more universities in the UK and internationally teach their students mindfulness skills, on various courses and to varying degrees, some have been doing this for several decades (Hassed \& Chambers, 2014). University students are equally vulnerable to mental distress as the general population (The Insight Network and Dig-In University Student Mental Health Survey, 2019). The pressure and stress inherent in embarking on a university course may test the most resilient of students or overwhelm others who may be less mentally prepared, spiralling their suffering to a point that will require support. Although, mental health services for students are increasingly available to varying degrees, it does raise questions about the preventative strategies on offer. The Higher

Education Academy (2017) recommends embedding health and wellbeing within the curriculum, offering examples of good practice and making encouraging suggestions such as offering mindfulness courses to university students. Skills in mindfulness could support the 
development of greater awareness amongst students enabling them to recognise the signs of stress at the point where they can proactively respond well before academic advisors or others become aware. A recent document 'A Positive and Mindful University' published by The Higher Education Policy Institute proposes a new proactive vision for higher education (Seldon \& Martin, 2017) that encourages the availability of mindfulness courses for university students. Similarly, promising findings are beginning to emerge from studies evaluating the effectiveness of mindfulness programmes aimed at well university student populations (Galante, et al. 2017).

\section{Mindfulness in nurse education}

The emotional demands that nurses endure can contribute to stress and burnout. In addition to the importance of sleep, diet and exercise, mindfulness is an element of 'self-care' (Blum, 2014) that aims to improve the health and wellbeing of nurses whom can often care for others, instead of caring for themselves. Development of self-care skills are well placed in the education of future nurses before they embark on their career as a professional. Furthermore, the aspirational values within the Jane Cumming's Compassionate Practice (Department of Health, 2012) more commonly known as the six C's, echoes the foundational attitudes (KabatZinn, 1990) inherent in practicing mindfulness, in that they share a holistic vision in how we, nurses, aspire to care for others. However, if we neglect ourselves over the people we care for we fail to recognise our own limitations, vulnerability and overall wellbeing. We ought to be more proactive in prioritising our wellbeing both for ourselves and for the people we care for.

Recently, the NMC (2018) published new future nurse proficiencies, stating that nurses "must be emotionally intelligent and resilient individuals" (p.3). It is hoped that this vision of future nurse education intends to cultivate, through awareness, a greater sensitivity to emotions of self and others, then develop a passive or desensitised approach to adversity. The increased level of awareness, reduced reactivity and skills developed through mindfulness courses could restore the balance putting self-care alongside the care of others. White (2014) conducted a concept analysis exploring mindfulness in nursing, concluding that mindfulness could support well-being and self-care in the field. Similarly, a review of the effectiveness of mindfulness meditation in student nurses internationally recommend that mindfulness meditation and yoga ought to be incorporated into the pre-registration programmes because of the effects 
of the positive impact on stress, sense of mental well-being and empathy (van der Riet, LevettJones \& Aquino-Russell, 2018). Furthermore, Snowden, Stenhouse, Young, Carver \& Brown (2015) suggested that enhancing emotional and cognitive abilities in pre-nursing programmes in their research on the relationship between emotional intelligence and mindfulness training. Research literature on mindfulness in nurse education in recent years, remains very limited in the UK, because they tend to be small in size and lack robust designs, which raises questions about their validity and reliability. However, studies do report that mindfulness in nurse education has a positive impact on students (Walker \& Mann, 2016; Van der Riet, Rossiter, Kirby, Dluzewska \& Harmon, 2015; Sanko, Mckay and Rogers, 2016; Dubert, Schumacher, Locker, Guterrez \& Barnes, 2016).

Perhaps consideration should be given to the persuasive research available of mindfulness meditation in general, because student nurses are people first, before they become university students. Further evaluative research is essential, especially now mindfulness interventions/programmes are now being offered in Universities and within nurse educational programmes. This is needed not only to highlight the benefits and utility of mindfulness in nurse education. In addition, future research endeavours need to consider, fine tuning and adapting mindfulness training/programmes to the specific student nurse populations, while keeping fidelity to the underlining mindfulness philosophy, but also give careful attention to the safety and support of participants (Britton, 2018; Lindahl, Fisher, Cooper, Rosen \& Britton, 2017).

\section{Conclusion}

The value of mindfulness meditation is a growing scientific field that is offered in various health care and educational environments including higher education. Although, there is limited specific research on the effect of delivering mindfulness courses to student nurses, there is research that mindfulness courses such as MBSR can benefit people in general. Consideration ought to be given to proactively offering such evidenced base courses that increase emotional intelligence, through developing skills such as emotional self-awareness, greater focused attention/concentration, presence and self-care. This could improve how student nurses experience the stress and challenges they are likely to encounter. These skills could offer an important addition to reflection for future practitioners. More importantly a mindful registrant may become a more effective, compassionate and caring nurse. 


\section{References:}

Blum, C, A. (2014). Practicing self-care for nurses: A nursing program initiative. Online Journal of Nursing Issues. Vol, 13(3). Retrieved from http://www.nursingworld.org/MainMenuCategories/ANAMarketplace/ANAPeriodica Is/OJIN/TableofContents/Vol-19-2014/No3-Sept-2014/Practicing-Self-Care-forNurses.html

Bodhi, B. (2011). What does mindfulness really mean? A canonical perspective. Contemporary Buddhism, Vol, 12 (1), 19-39.

Britton, W. B. (2016). Scientific literacy as a foundational competency for teachers of mindfulness based courses. In D. McCown, D. Reibel \& M. S. Micozzi (Eds.), Resources for teaching mindfulness an international handbook. New York: Springer.

Britton, W. B. (2018). Meditation safety toolbox. Retrieved from https://www.brown.edu/research/labs/britton/resources/meditation-safety-toolbox

Crane, R. S., Eames, C., Kuyken, W., Hastings, R. P., Williams, J. M. G., Bartley, T., Evans, A., Silverton, S., Soulsby, J. G., \& Surawy, C. (2013). Development and validation of the mindfulness-based interventions - teaching assessment criteria (MBI:TAC). Assessment, 20 (6), 681-688. doi: 10.1177/1073191113490790

Department of Health. (2012). Compassionate practice. Retrieved from https://www.england.nhs.uk/wp-content/uploads/2012/12/compassion-inpractice.pdf

Dubert, C. J., Schumacher, A. M., Locker Jr. L., Gutierrez, A. P. \& Barnes, V. A. (2016). Mindfulness and emotion regulation among nursing students: Investigating the mediation effect of working memory capacity. Mindfulness. Vol, 7(5), 1061-1070.

Galante, J., Dufour, G., Vainre, M., Wagner, A. P., Stochl, J., Benton, A., Lathia, N., Howarth, E. \& Jones, P. B. (2017). A mindfulness-based intervention to increase resilience to stress in university students (the Mindful Student Study): a pragmatic randomised controlled trial. Lancet Public Health. Vol, 2 (3), 72-81. Retrieved from https://www.thelancet.com/journals/lanpub/article/PIIS2468-2667(17)302311/fulltext 
Goleman, D. \& Davidson, J. R. (2017). The science of meditation: how to change your brain, mind and body. Milton Keynes, UK: Penguin Random House.

Hassed, C. \& Chambers, R. (2014). Mindful Learning: mindfulness-based techniques for educators and parents to help students. Boston, MA: Shambhala.

Higher Education Academy. (2017). Embedding mental wellbeing in the curriculum: maximising success in higher education. Retrieved from https://www.heacademy.ac.uk/knowledge-hub/embedding-mental-wellbeingcurriculum-maximising-success-higher-education

Howland, L. C. \& Bauer-Wu, S. (2015). The mindful nurse. American Nurse Today. Vol 10 (9), 12-13 \& 43. Retrieved from https://www.americannursetoday.com/mindful-nurse/

Kabat-Zinn, J. (1990). Full catastrophe living, revised edition: How to cope with stress, pain and illness using mindfulness meditation. London: Piatkus.

Kabat-Zinn, J. (1994). Wherever you go, there you are. New York: Hyperion.

Lindahl, J. R., Fisher, N. E., Cooper, D.J., Rosen, R. K. \& Britton, W. B. (2017) The varieties of contemplative experience: A mixed-methods study of meditation-related challenges in Western Buddhists. PLoS ONE, Vol, 12(5), 1-38 e0176239.

\section{https://doi.org/10.1371/journal.pone.0176239}

Moon, J. A. (1999). Reflection in learning and professional development: theory and practice. Oxon: RoutledgeFalmer.

Moon, J. A. (2004) A Handbook of reflective and experiential learning: Theory and practice, Oxen, UK: RoutledgeFalmer

National Institute for Health and Clinical Excellence. (2009). Depression: the treatment and management of depression in adults. Retrieved from https://www.nice.org.uk/guidance/cg90/evidence/full-guidance-243833293

Neves, J. \& Hillman, N. (2016). The 2016 Student Academic Experience Survey. York: Higher Education Academy

Nursing and Midwifery Council (NMC). (2018). Future nurse: Standards of proficiency for registered nurses Retrieved from 
https://www.nmc.org.uk/globalassets/sitedocuments/education-standards/futurenurse-proficiencies.pdf

Oates, J. (2017). Editorial: Being a mental health nurse. Journal Psychiatric Mental Health Nursing. Vol, 24:469-470.

Pipe, T., FitzPatrick, K., Doucette, J. N., Cotton, A. \& Arnow, D. (2016). The mindful part 1: Improving processes and outcomes; restoring joy to nursing. Nursing Management. Vol, 47 (9) 44-48.

Sanko, J., Mckay, M. \& Rogers, S. (2016). Exploring the impact of mindfulness meditation training in pre-licensure and post graduate nurses. Nurse Education Today. Vol, 45, 141-147.

Santorelli, S. F., Meleo-Meyer, F., Koerbel, L. (2017). Mindfulness-based stress reduction (MBSR) curriculum guide. University of Massachusetts Medical School. Retrieved from https://www.umassmed.edu/globalassets/center-formindfulness/documents/mbsr-curriculum-guide-2017.pdf

Schon, D. (1983). The Reflective Practitioner. London, UK: Temple Smith.

Segal, Z. V. Williams, J. M. G., \& Teasdale, J. D. (2013). Mindfulness-based cognitive therapy for depression. (2nd ed.). New York, NY: The Guildford Press.

Seldon, A. \& Martin, A. (2017). The positive and mindful university. The Higher Education Policy Institute. Retrieved from http://www.hepi.ac.uk/2017/09/21/positivemindful-university/

Sheridan, C. (2016). The mindful nurse: Using the power of mindfulness and compassion to help you thrive in your work. USA: Rivertime Press.

Snowden, A., Stenhouse, R., Young, J., Carver, H. \& Brown, N. (2015). The relationship between emotional intelligence, previous caring experience and mindfulness in student nurses and midwives: a cross sectional analysis. Nurse Education Today. Vol, $35,152-158$. 
The Insight Network and Dig-In University Student Mental Health Survey. (2019). University student mental health survey 2018. Retrieved from https://www.diginbox.com/mental-health-report-2018

The Mindfulness All-Party Parliamentary Group (MAPPG). (2015). Mindful Nation UK. The mindfulness initiative. Retrieved from http://themindfulnessinitiative.org.uk/images/reports/Mindfulness-APPGReport Mindful-Nation-UK Oct2015.pdf

Thera, N. (1962). The heart of Buddhist meditation. London, UK: Rider \& Co.

Van Dam, N. T., Vugt, M. K., David R. Vago, D. R., Scmalzl, L., Saron, C. D., Olendzki, A., Meissner, T., Lazar, S. L., Kerr, C. E., Gorchov, J., Kieran C. R. Fox, K. C. R., Field, B. A. Willoughby B. Britton, W. B., Brefczynski-Lewis, J. A. \& Meyer, D. E. (2017). Mind the hype: A critical evaluation and prescriptive agenda for research on mindfulness and meditation. Perspectives on Psychological Science, 1-26 doi: $10.1177 / 1745691617709589$

Van der Riet, P., Levett-Jones, T. \& Aquino-Russell, C. (2018). The effectiveness of mindfulness meditation for nurses and nursing students: An integrated literature review. Nurse Education Today, Vol, 65, 201-211. doi.org/10.1016/j.nedt.2018.03.018

Van der Riet, P., Rossiter, R., Kirby, D., Dluzewskad, T. \& Harmon, C. (2015). Piloting a stress management and mindfulness program for undergraduate nursing students: Student feedback and lessons learned. Nurse Education Today. Vol, 35(1), 44-49.

Walker, M. \& Mann, R. A. (2016). Exploration of mindfulness in relation to compassion, empathy and reflection within nursing education. Nurse Education Today, Vol, 40, 188-190.

White, L. (2014). Mindfulness in nursing: An evolutionary concept analysis. Journal of Advanced Nursing, 70(2), 282-294. doi: 10.1111/jan.12182

Wyder, M., Ehrlich, C., Crompton, D., McArthur, L., Delaforce, C., Dziopa, F., Ramon, S. and Powell, E. (2017), Nurses experiences of delivering care in acute inpatient mental 
health settings: A narrative synthesis of the literature. International Journal of Mental Health Nursing. doi:10.1111/inm.12315 